\title{
Electoral Support for the Czech Green Party in Relation to Post-Materialism, 2006-2013
}

\author{
Michal PinK, ONDŘEJ SAX AND ANDREA SMOLKOVÁ ${ }^{1}$
}

\begin{abstract}
The article analyses the relationship between electoral support of the Green Party in the Czech Republic and the level of post-materialism on municipal level. Indicators of post-materialism (lower age, university education, middle and upper class/income, lower unemployment rate in the municipality, and larger municipality size) are based on the concept of post-materialism developed by Ronald Inglehart as well as other studies. The study analyses data aggregated at the municipal level, first for the whole nation and then in more depth for two selected regions. Quantitative methods and techniques, mainly correlation and regression, are used to determine the relationship between the variables. We find that although there are connections and influences between post-materially oriented regions and support for the Green Party, the relationship is not particularly strong.
\end{abstract}

Keywords: Czech Green Party; Post-materialism; Ronald Inglehart; the Czech Republic; Electoral results

\section{Introduction}

The introduction of a liberal democratic political regime in the Czech Republic has resulted in free competition between political parties in regularly recurring elections. A party system has gradually established itself, in which the main political parties have established positions; thus, the Czech political landscape increasingly resembles the established regimes of Western Europe. In addition to the large political parties, the smaller Green Party has progressively asserted itself; indeed, in organizational terms, it is now one of the longest established parties in the Czech electoral arena. Since its foundation in 1989, it has undergone development and witnessed changes to both personnel and programmes. It has also seen reversals of fortune: transitioning from a marginal party during the

\footnotetext{
1 All authors: Department of Political Science, Faculty of Social Studies, Masaryk University, Joštova 10, 602 00, Brno, Czech Republic. E-mail: pink@fss.muni.cz (Michal Pink); 374483@mail.muni.cz (Ondřej Sax), andrea.smolkova@mail.muni.cz (Andrea Smolková). This article is an output of a Czech Science Foundation grant, code GA15-2274S (Quality of Democracy: Crech Republic in Comparative Perspective).
} 
1990s to a member of the government coalition in 2007-2009. It subsequently lost representation in the lower chamber of the Czech Parliament; however, Eliška Wagnerová for the Brno-city constituency and a few others continue to represent it in the upper chamber (the Senate).

Representing environmental interests in Czech party politics, the Green Party is a full member of the European Green Party and the Global Greens. Yet the question remains: are the areas it draws support from, and its voters, comparable to those of other 'green' parties in Europe and worldwide? If the Czech Republic is now a fully consolidated democracy (Møller 2009; Balík et al. 2008) does this also mean that 25 years after the fall of the communist regime, the Czech electoral arena is now ready for a post-materialist party in a Western European vein? These, in brief, are the questions framing the issues this article explores. In this paper we analyse election results of the Green party and the spatial differentiation of its support, with respect to local characteristics and specificities.

Our main objective is to answer the following question: Is there a relationship between the election results of the Czech Green Party and the proportion of voters with post-materialist values in a municipality? Indicators of post-materialism are derived from previous studies (Inglehart 1977; Rabušic 2000) and described later on in the article.

The article is divided into several sections. After this introduction follows a presentation of the Green Party and its possible programmatic links with post-materialism, a concept defined by Ronald Inglehart (1971; 1977). Basic variables are then defined, which provide a key to the dependencies affecting voting behaviour; and the concluding sections seek to establish the relationships and potential influences expected to clarify the Green Party's sources of legitimacy. The basic theoretical framework is provided by the concept of post-materialism; the database consists of election results and the outputs of the 2011 Population and Housing Census, aggregated to the level of municipalities, and provided by the Czech Statistical Office.

\section{Ronald Inglehart's Concept of Post-Materialism and the Czech Green Party}

It may at first glance seem somewhat paradoxical that while Inglehart defined the post-materialist society as one made up chiefly of the younger cohorts of the middle classes in receipt of higher education (Inglehart 1971; 1977), post-materialists are more than likely to favour changes in society and social innovation, a feature more characteristic of left-wing parties (Chytilek 2000). Inglehart contended that, with the rise of post-materialism, it is no longer appropriate to examine the relationship between social class and left- or right-wing allegiances, or the relationship between social class and election results. For this he has been criticized, chiefly by Weakliem (1991), who sought to prove that the opposite holds true on the basis of his own 
research conducted with voters in France, Italy, and the Netherlands; i.e. a sample of voters from Western democracies constituting typical examples of Inglehart's post-industrial and post-materialist societies.

Inglehart was relatively skilful in classifying the post-materialist parties and movements under the rubric of 'New Politics'. However, given the values they typically espouse, minority rights, pacifism, environmentalism, and social change, these entities tend to be placed on the left side of the left-to-right scale. To establish their position, Inglehart once again developed his own instrument, examining the stance of the post-materialists on issues typically salient in a materialist society, especially the economy. Such an approach does not make it very easy to ascertain the position of the post-materialist parties within the political spectrum, as they are in ideological conflict with both the right and the classical left. This, in turn, problematized the position of the latter, which was expected to respond to the rise of 'New Politics' (Chytilek 2000). As the classic parties of the left introduced post-materialist values into their programmes, and modernized and democratized themselves, they lost some of their traditional members and supporters, the lower-class workers. Having obtained social security, this group no longer favoured social change; conversely, it felt threatened by post-materialism, thus becoming an electoral bank for the right wing, in some cases even far-right parties (Chytilek 2000). In view of this phenomenon, Inglehart described right-wing parties as a bastion of materialism. Voter volatility and shifts in support for the political parties also occurred in the Czech electoral arena; as evident in the decline in electoral support for the Green Party during the second half of the 1990s (Pečínka 2002).

Since Inglehart denies that post-materialism is to be found on the right of the political spectrum, one must mention the most vocal critic of this aspect in his work, Pietro Ignazi (1996; 1992). Ignazi analysed two types of political currents, which witnessed an unprecedented rise in electoral support during the 1970s and 1980s: the Greens and the extreme right. As far as the Greens are concerned, Ignazi effectively agrees with Inglehart's definition of New Politics, maintaining that these are not just environmentalists, since pacifism and other values are evident in the movement. Ignazi argues that the emergence of the Greens and the far right is the result of a structural transformation of society, a transformation, which gave rise to post-materialist values. Inglehart's basic socialization hypothesis envisages change only as regards value priorities, and not in political thinking.

Although Inglehart only considers post-materialism in established Western democratic systems, such values can also be observed in Central and Eastern Europe. Several years after the fall of the Iron Curtain, the need for physical and economic security is no longer felt so acutely (see below), and political parties and movements accentuating post-materialist values, and responding to the demand for such values, are emerging in the post-communist world, the Czech Green 
Party being one such party. In part, this is a response to the long years of the communist regime.

On the subject of post-materialism and the Czech electoral arena, or more precisely, Czech society, four surveys based on Inglehart's methodology have been undertaken in the country since the fall of communism. Rabušic (2000) summarized the results of these surveys. Assuming that Inglehart's measurement technique and typology are accepted as valid, the post-materialist dimension has been present and growing among the Czech population, especially among the young adults. Research on this has also been carried out within the framework of the World Values Survey (WVS) and the European Values Study (EVS). All these surveys were strictly sociological in character and none were explicitly concerned with the Green Party or any other environmental movement or political entity, or election results. In these surveys, Inglehart and German political scientist, Christian Welzel, studied countries worldwide, to create a map of values in the world (World Values Survey 2014). Countries were mapped along two axes based on their positions, the first representing the scale of traditional values vs. secular-rational values, and the other that of survival values vs. self-expression values, which reflects the main cleavage of materialism vs. post-materialism. A cluster of post-communist countries emerged on the Inglehart and Wenzel map, of which the Czech Republic achieved the highest position on both axes, i.e. it is considered the most post-materialistic of the post-communist countries (World Values Survey 2014).

Admittedly, Inglehart's notion of post-materialism has been used rather freely, both in the Czech Republic and abroad (cf. Rabušic 2000). To some extent, this may be due to the fact that Inglehart himself did not clearly define specific indicators to measure post-materialism. Also, one needs to consider that society evolves naturally, and so does its political system - thus, both are subject to change. These facts may constrain any research undertaken in this area. Post-materialism has generally been measured in value surveys using four, and, later, 12 statements. For the Czech Republic, there is no data available from before the 1989 revolution. Thus, we can only analyse a shorter period of time than in Western countries - yet there are data available on which we can draw. A post-materialist index has been included in the following surveys that involved the Czechs: the European Values Study 1991, 1999 and 2008; the World Values Survey 1990 and 1995; the International Social Survey Program 1993 and 2000; and the Family and Fertility Survey 1997 (Rabušic 2000).

\section{Data and Sources}

Methodologically, our research faced certain limitations from the outset, most notably the limited accessibility of data necessary in order to undertake the analysis. More importantly, we needed to face the fact that we would be working 
with aggregated data: the research does not deal with individual voters, but with data collected for the observed municipalities, that is, with election results and socio-economic indicators. The main dependent variable is the share of the vote polled by the Green Party at the level of individual municipalities, expressed as a percentage and weighted by the population size of the municipality. Given that there have been minor changes in the number of municipalities and their administrations, with some settlement units registered as military districts, the number of units has been brought to 6,241, i.e. the situation as of 1 January 2013, the beginning of the year in which the most recent observed elections to the Chamber of Deputies took place.

All the conclusions obtained will therefore be valid for the territorial units observed, and not for the level of the individual voters. By emphasizing this fact, we seek to avoid committing the regrettably frequent ecological fallacy. Nonetheless, work with aggregated data is a standard procedure in election studies (for examples of Czech scholarship, see Kostelecký 2009; Jehlička et al 2011), and when interpreted correctly, such data facilitates examination of the influence of a range of variables on electoral support for parties.

Our article employs classical statistical methods. The first important step is to determine the coefficient of variation, which shows the extent of the variability of data in relation to the mean (Hendl 2006). The coefficient of variation will help us establish whether, and to what degree, regional variability changes. Thus, having calculated the coefficient of variation, we will be able to ascertain whether the differences between the units studied increased, decreased, or remained the same. Correlation analysis will be applied as part of the next step, for which purpose the Pearson's coefficient of correlation was adopted. With the help of this coefficient, we will be able to ascertain the relationship between the spatial distribution of electoral support, and selected variables that may influence the decision-making of voters in the localities observed. A correlation analysis cannot ascertain a causal relationship; hence, a regression analysis will also be undertaken, which will allow us to establish how the value of the dependent variable changes when the value of an independent variable alters by one unit. The data used for the spatial analysis was aggregated at the level of the municipalities, and obtained from the Czech Statistical Office (volby.cz, Population and Housing Census, and other databases) and from other statistical sources; for example, the publicly available databases of the Ministry of Labour and Social Affairs. For the purposes of answering our research question, data aggregated at municipal level is sufficient. For further possible comparisons between regions, data aggregated at the regional level will also be used. We have chosen aggregate data because it is relatively readily available (Kostelecký and Čermák 2003). 


\section{a. Selecting the Indicators}

As Rabušic (2000) stated, when studying value orientations, the problem is always encountered, that values cannot be observed directly; thus, one must study indicators thereof. Drawing on the existing knowledge of the topic, as summarized above, we have selected five indicators characterizing the typical post-materialist Czech Green Party voter. They are based on the prevailing theoretical framework and consider the practical availability of the data for the chosen level of aggregation, that is the individual municipalities.

\section{LOWER AGE}

Inglehart's original thesis about intergenerational value change assumed two relationships between age and values. The younger generations tend to espouse more post-materialistic values than the older generations, which lean towards materialistic values (Inglehart 1971; 1977; cf. Tranter and Western 2004). Given that twenty-five years have elapsed between November 1989 and the writing of this paper, we must consider that the core of the Green Party's electoral group has now come of age, necessitating the expansion of the age bracket, which we set as 19 to 29 years. The upper boundary has been chosen in consideration of the terminology employed by Matilda White Riley (1972) who used the term 'younger generation'. Thus, the indicator specified will relate to the proportion of inhabitants (or more precisely, the proportion of voters) in a municipality falling into this age group.

\section{MidDle AND UPPER Class/INCOME}

Inglehart indicates that the post-materialist voter does not experience material want. However, he only uses the term middle class in this context without further clarification. Thus, although Inglehart only writes about the middle classes, logic dictates that we include the members of the upper classes as well. Indeed, if members of the middle classes have ceased to experience material want, one cannot leave out the members of the upper class, who feel barely any lack of economic or physical security whatsoever. Duch and Taylor (1993), who have studied post-materialism in connection with economic condition, have proposed a similar argument. Considering Central Europe, and more specifically, the Czech Republic, Večerník and Matějů (1998) included, as the foremost representatives of the middle classes, what the current legal regulations call 'self-employed persons', as they are business owners commanding a certain amount of capital. They offer a contrast with the aristocracy and the rentier class. Večerník and Matěju (1998) also pointed out the significance of the long-term absence of a middle class in Czech society from 1948 to 1989, when the communist regime actively sought to 
suppress them. ${ }^{2}$ Most applicable to this article are income-based definitions of middle class common in the economic literature (e.g. OECD 2010; Easterly 2001), which are relatively easy to operationalize. Therefore, the middle class will be defined on the basis of average monthly income. Given that according to the notions outlined above, both wage earners and the self-employed are thought to belong to the middle classes, we will consider the average earnings of both categories. The average salary thus defined is our second indicator, with the threshold set at CZK 23,795 (approx. 250 EUR) a month, which is the most recent figure (for 2012), as provided by the Czech Statistical Office (ČSÚ 2012). This figure is well represented by the indicator 'purchasing power', expressed as the average monthly income per capita in thousands of Czech crowns. These data do not originate from the Population and Housing Census, but from the company GFK Incoma. Unfortunately, the company does not make public the exact procedure used to obtain these data. However, the description of the data set indicates that the data reflect salaries in the public and private sectors, as well as payments received in the form of pensions and welfare at the level of individual municipalities. Though the data cannot be understood as a perfect measure of average income in municipalities due to issues of methodology, they probably describe inter-regional differences in income levels with sufficient validity.

\section{UNIVERSITY EDUCATION}

University education is linked to growing affluence in society. When young people extend their education this is an indicator that it is no longer necessary for them to seek gainful employment as early as possible in their lives. According to Inglehart, it is also one of the defining characteristics of post-materialist cohorts, since the rise of culturally progressive values is linked to a higher level of education (cf. Lipsitz 1965; Lipset 1981). As some authors (Berger 1986; Večerník and Matějů 1998) have asserted, a higher-level education is one of the conditions of inclusion in the middle classes. Lipset (1981) has linked the standard of education with social status, a position of power, a particular type of occupation, and the size of property owned. Thus, the relationship between educational level achieved and membership in a social class is a substantial one. The data on educational level achieved was adopted from the most recent Population and Housing Census, undertaken by the Czech Statistical Office in 2011 (SLDB 2011). The proportion of the population with a university education is therefore our next indicator.

\section{SiZE OF MUNICIPALITY (CITY)}

As indicated above, the profile of the Czech post-materialist voter is almost identical to that of his counterpart in Western Europe. The indicator of the size of

\footnotetext{
2 The communist regime persecuted not only capital owners, but also those with higher education and the so-called intelligentsia.
} 
the municipality in which such voter lives is no exception to this; we assume that larger cities feature a higher concentration of post-materialist voters than smaller municipalities (Burchell 2002). Data on the basis of which municipalities are included in our category of 'City' is provided by the databases of the Czech Statistical Office (ČSÚ 2014). All municipalities are classified into two categories "City/others".

\section{UNEMPLOYMENT RATE}

Another key indicator linked with post-materialist voters is that low unemployment rate in an area may indicate that higher than average post-materialistic values are more prevalent there. A voter in employment is not lacking in economic or physical security, and thus in their decision-making they can consider post-materialistic values, and not primarily or exclusively their class affiliation. Tranter and Western (2009) pointed this out. Therefore, our final indicator will be the unemployment rate in the municipalities, as published in regular overviews by the Czech Ministry of Labour and Social Affairs. The values considered will always be the closest available to the date of the election (MPSV 2014).

\section{The Czech Green Party}

\section{a. Electoral gains}

The work of Jehlička, Kostelecký and Kunštát (2011) provided a basic overview of the workings of the Czech Green Party; therefore, we limit ourselves here to a brief recapitulation of how this environmental party fares in the Czech situation.

Activities undertaken by various pacific and environmental movements, in what is today the Czech Republic, can be traced back to dissident circles active prior to 1989. The first Green party was established in Czechoslovakia in November 1989, under the name the Czechoslovak Green Party. However, due to internal disputes, personal issues, and organizational shortcomings, it was quickly discredited in the eyes of the electorate. For several years, disputes and a lack of unity characterized the party. It was only at the turn of the millennium that the Green Party began to transform itself ideologically, distancing itself from nuclear power, demanding better protection of minorities, civil partnership for same-sex couples, and the preservation of free education. It also promoted elements of direct democracy and pushed for a reduction in the national electoral threshold from $5 \%$ to $3 \%$, supporting EU accession and the disbanding of military blocs, etc. This programme brought it closer to the European 'green' parties (Pećínka 2002). The party gained some popularity ahead of the 2002 election in to the Chamber of Deputies, in which it polled $2.36 \%$ of the vote. The spatial distribution of its support, however, had changed significantly since the previous elections, as in 2002 it obtained the majority of its votes in the capital. Although the party failed to cross the $5 \%$ threshold, it obtained a state subsidy for 
its operations and was able to develop a range of its activities further. The Green Party witnessed its greatest success in the 2006 election, when, led by Martin Bursík, it crossed the 5\% threshold, and subsequently entered centre-right government alongside ODS and KDU-ČSL. However, during its period in government, significant discord emerged in the party, which ultimately (together with discord within other coalition parties) contributed to the downfall of Topolánek's second government, which was then replaced by a caretaker administration. In 2010 and in the early election of 2013, the Green Party was the first party to fail to cross the 5\% threshold, with $2,44 \%$ in 2010 and $3.19 \%$ of the vote in 2013; this once again made it eligible for a state subsidy for its operations (see Table 1). At the time of writing, the party lacks representation in the lower chamber of the national parliament. It has, however, won seats in the Senate recently: since 2012 it has had two senators, Eliška Wagnerová and Libor Michálek. Other environmental parties exist in the Czech Republic, but they are comparatively marginal.

Table 1: Gains of the Green Party in elections to the Chamber of Deputies of the Czech Parliament

\begin{tabular}{|c|c|c|c|c|c|}
\hline Year & $\begin{array}{c}\text { Number of } \\
\text { voters }\end{array}$ & $\begin{array}{c}\text { Number of valid } \\
\text { votes cast }\end{array}$ & $\begin{array}{c}\text { Number of } \\
\text { votes cast for } \\
\text { the Green Party }\end{array}$ & $\begin{array}{c}\text { Green Party's } \\
\text { share of the } \\
\text { vote }\end{array}$ & Seats \\
\hline 1996 & $7,990,770$ & $6,059,215$ & 0 & 0 & 0 \\
\hline 1998 & $8,116,863$ & $5,969,505$ & 67,143 & 1.12 & 0 \\
\hline 2002 & $8,264,484$ & $4,768,006$ & 112,929 & 2.36 & 0 \\
\hline 2006 & $8,333,305$ & $5,348,976$ & 336,487 & 6.29 & 6 \\
\hline 2010 & $8,415,892$ & $5,230,859$ & 127,831 & 2.44 & 0 \\
\hline 2013 & $8,424,227$ & $4,969,984$ & 159,025 & 3.19 & 0 \\
\hline
\end{tabular}

Source: Official electoral data website of the Czech Statistical office (www.volby.cz).

Table 2: Descriptive characteristics of Green Party's gains in elections to the Chamber of Deputies $(\mathrm{N}=6,241)$

\begin{tabular}{|c|c|c|c|c|c|c|c|}
\hline Year & Mean & Median & Mode & $\begin{array}{c}\text { Standard } \\
\text { deviation }\end{array}$ & Variance & Min. & Max. \\
\hline 2006 & 4.82 & 4.58 & 0.00 & 2.61 & 6,81 & 0.00 & 32.96 \\
\hline 2010 & 1.69 & 1.49 & 0.00 & 1.47 & 2.16 & 0.00 & 30.30 \\
\hline 2013 & 2.15 & 1.94 & 0.00 & 1.67 & 2.78 & 0.00 & 17.07 \\
\hline
\end{tabular}

Source: www.volby.cz, authors' calculation. 
Table 2 summarizes the results achieved by the Green Party in the three elections to the Chamber of Deputies studied. The variables provided cover all the municipalities. The mode, which is the value that appears most often in a set of data, has been zero for all three elections. In other words, in a large number of municipalities throughout the Czech Republic the Green Party has failed to win a single vote. The median, which is the value that splits the data set observed into two halves, was lowest in 2010, and highest in 2006 (when the party won six seats). The values of the mean have always been somewhat higher than the values of the median. The standard deviation indicates a concentration of data around the mean. The lower the value of the standard deviation, the higher the concentration around the mean. This phenomenon was particularly conspicuous in the most recent election in 2013.

Table 3: Variability in electoral support for the Green Party $(\mathrm{N}=6,241)$

\begin{tabular}{|c|c|c|c|}
\hline & $\mathbf{2 0 0 6}$ & $\mathbf{2 0 1 0}$ & $\mathbf{2 0 1 3}$ \\
\hline $\begin{array}{c}\text { Coefficient of } \\
\text { variation }\end{array}$ & 0.54 & 0.87 & 0.78 \\
\hline
\end{tabular}

Source: www.volby.cz, authors' calculation.

In Table 3, the coefficient of variation indicates the territorial variability of electoral support: the higher its value, the more support for the party varies across municipalities. The values of the coefficient are relatively high for all three elections, indicating that electoral support for the party has spread unevenly across the country. The values for the coefficient of variation correspond with the values presented in the previous table, in particular, the value of the mode, and that of the minimum share of vote won. In other words, this tells us that there are municipalities where the Green Party obtained zero votes. In order to further elucidate and understand the continuity between the three elections studied, we present a correlation analysis.

Table 4: Stability of the Green Party's electoral base $(\mathrm{N}=6,241)$

\begin{tabular}{|c|c|c|c|}
\hline & $\mathbf{2 0 0 6}$ & $\mathbf{2 0 1 0}$ & $\mathbf{2 0 1 3}$ \\
\hline 2006 & 1 & 0.685 & 0.654 \\
\hline 2010 & 0.685 & 1 & 0.824 \\
\hline 2013 & 0.654 & 0.824 & 1 \\
\hline
\end{tabular}

Note: Figures in the table represent Pearson's coefficient of correlation; weighted by the population living in municipalities in 2010.

Source: www.volby.cz, authors' calculation. 
Using the values of Pearson's coefficient of correlation, Table 4 illustrates the stability of the Green Party's electoral base over the three most recent elections to the Chamber of Deputies. The values reveal that the relationship between the various electoral results analysed is fairly high and the municipalities with higher support for Green Party in one election could vote for Green Party next time.

\section{b. Indicators of Post-Materialism and Electoral Support}

Using a correlation analysis, we now present the relationship between the electoral gains of the Green Party and the selected contextual factors representing the five indicators of post-materialism. Table 5 reveals that the correlation between electoral support for the Green Party on the one hand, and municipalities with a higher proportion of voters with a university education on the other, is positive and the highest among the correlations studied. In these cases, the values of the coefficient are higher than 0.6. The relationship between electoral support and a higher proportion of middle and upper-class voters is higher than 0.4. In the case of the variable 'city' it is very similar than that involving the variable 'middle and upper class/income'. Relationship with the variable 'unemployment' is negative, as is the case with the variable 'lower age' in 2013.

Table 5: Correlations between electoral support and indic. of post-materialism $(\mathrm{N}=6,241)$

\begin{tabular}{|l|c|c|c|}
\hline & $\mathbf{2 0 0 6}$ & $\mathbf{2 0 1 0}$ & $\mathbf{2 0 1 3}$ \\
\hline Lower age & 0.066 & 0.085 & -0.216 \\
\hline $\begin{array}{l}\text { Middle and upper } \\
\text { class/income }\end{array}$ & 0.401 & 0.500 & 0.581 \\
\hline University education & 0.601 & 0.708 & 0.803 \\
\hline City & 0.478 & 0.520 & 0.559 \\
\hline Unemployment rate & -0.404 & -0.458 & -0.313 \\
\hline
\end{tabular}

Note: weighted by the population living in municipalities in 2010 .

Source: www.volby.cz, www.czso.cz, www.mpsv.cz, authors' calculation.

The overall results indicate that, out of a total of five indicators of postmaterialism, there is a moderate relationship between each other. The indicators that do not appear relate to the Green Party's election results are the following: lower age and unemployment rate.

Let us proceed to a linear regression in order to express the relationships among the variables more precisely. Table 6 summarizes the values of the beta coefficient, indicating how far the value of the explained variable changes when the value of an independent variable is shifted by one unit. The dependent variable here 
is the electoral gains of the Green Party in 2006, 2010 and 2013. There are five independent variables, consisting of the indicators of post-materialism, as defined above. Before proceeding to interpret the values in the table, two further values significant for a regression analysis must be mentioned. The index of determination, indicating the proportion of explained variability in the data set observed, reached comparatively higher values of above 0.4 or 0.6 . Thus, our conclusions are valid for more than $40-60 \%$ of the units observed. The highest values of standardized beta coefficient were recorded for the variables, 'university education' and, in some cases, 'city'. By contrast, the values were not negative, or low like variable 'unemployment rate'.

Table 6: Parameters of regression model estimating the Green Party election results in municipalities in the Czech Republic $(N=6,241)$

\begin{tabular}{|l|c|c|c|c|c|c|}
\hline \multirow{2}{*}{} & \multicolumn{2}{|c|}{2006} & \multicolumn{2}{c|}{2010} & \multicolumn{2}{c|}{2013} \\
\cline { 2 - 7 } & Beta & St. Beta & Beta & St. Beta & Beta & St. Beta \\
\hline Constant & 4.613 & & -1.193 & & -1.825 & \\
\hline Lower age & 0.104 & 0.063 & 0.025 & 0.027 & -0.063 & -0.049 \\
\hline $\begin{array}{l}\text { Middle and upper class } \\
\text { /income }\end{array}$ & -0.010 & -0.048 & 0.019 & 0.150 & 0.035 & 0.211 \\
\hline University education & 0.156 & 0.391 & 0.120 & 0.530 & 0.189 & 0.622 \\
\hline City & 0.834 & 0.182 & 0.325 & 0.123 & 0.308 & 0.087 \\
\hline Unemployment rate & -0.115 & -0.233 & 0.000 & -0.001 & 0.035 & 0.056 \\
\hline Index of determination & \multicolumn{7}{|c|}{0.400} & \multicolumn{7}{|c|}{0.517} & \multicolumn{2}{c|}{0.662} \\
\hline
\end{tabular}

Note: weighted by the population living in municipalities in 2006, 2010 and 2013.

Source: www.volby.cz, www.czso.cz, www.mpsv.cz, authors' calculation.

Having summarized the beta coefficient, the relationships between electoral support for the Green Party and the indicators are noteworthy, demanding further study: 'university education', and 'city'. In relation to the most recent elections to the Chamber of Deputies 2013, we can predict that an increase of one unit in the proportion of members of the university education increase $0,20 \%$ of votes for Green Party. For the variables 'city' is it less important and 'lower unemployment rate', no important and positive causal relationship has been established at the level of municipalities on national scale; however, the relationship will be studied further at the lower level of two Czech regions. The variables cited will be evaluated in the conclusion, where answers to the research questions are provided.

\section{c. Analysis of Selected Regions}

In order to understand election results across the country and the variables that influence them better, it is necessary to focus on smaller territorial units. We have 
chosen higher territorial self-governing units, the regions. In the Czech case, these also served as constituencies within which seats are allocated. The results of the three most recent elections to the Chamber of Deputies will be analysed for all regions. Those regions in which the Green Party achieved its greatest successes will subsequently be analysed in greater depth. The results are outlined in Table $7:^{3}$

A brief glance at the table indicates that the party obtained its greatest gains in Prague, ${ }^{4}$ with a margin of almost two percentage points over other regions, with high percentage gains also recorded in the regions of Liberec and Central Bohemia. These two regions are therefore analysed in greater detail in the next section. The table also shows that the Green Party is comparatively more successful in Bohemia than in Moravia and Silesia.

Table 7: Electoral results of the Green Party in regions (in \%)

\begin{tabular}{|l|c|c|c|}
\hline & $\mathbf{2 0 0 6}$ & $\mathbf{2 0 1 0}$ & $\mathbf{2 0 1 3}$ \\
\hline Prague & 9.19 & 4.78 & 6.45 \\
\hline Central Bohemia & 6.00 & 2.32 & 3.70 \\
\hline South Bohemia & 5.90 & 2.17 & 2.46 \\
\hline Plzeň & 5.91 & 1.71 & 2.29 \\
\hline Karlovy Vary & 6.71 & 2.08 & 2.28 \\
\hline Ústí nad Labem & 6.03 & 2.41 & 2.68 \\
\hline Liberec & 9.58 & 2.60 & 2.54 \\
\hline Hradec Králové & 6.69 & 2.50 & 2.87 \\
\hline Pardubice & 6.26 & 1.86 & 2.53 \\
\hline Vysočina & 4.89 & 1.68 & 2.60 \\
\hline South Moravia & 6.20 & 2.34 & 3.27 \\
\hline Olomouc & 5.51 & 1.80 & 2.32 \\
\hline Zlín & 5.07 & 1.80 & 2.34 \\
\hline Moravia-Silesia & 4.34 & 1.93 & 2.39 \\
\hline
\end{tabular}

Source: www.volby.cz, authors' calculation.

3 For reasons of clarity of presentation and orientation in the results obtained, the analyses undertaken are recorded here in a simplified manner, with less detail provided than for those at the national level. For example, when analysing the regions descriptive statistics are entirely omitted and the results of the correlation analysis are not recorded. This especially concerns cases where the results of the correlation analysis were confirmed by regression analysis, with the regression analysis affording greater precision to the results.

${ }^{4}$ The capital, Prague, represents a specific research area. It would be methodologically imprecise to treat it as a single municipality; it is much more suitable to study its boroughs, or even electoral wards. There is, however, no space to do that here; hence, we have decided to omit Prague from our study. 


\section{CENTRAL BOHEMia}

Central Bohemia, one of the Czech Republic's largest regions, is characterized by its close links with Prague. Although in terms of geography Prague lies at the centre of the Central Bohemia region, it is in fact a distinct higher territorial self-governing unit (region). The close links between Prague and Central Bohemia might suggest the two regions are similar; however, they are somewhat different in both socioeconomic and demographic terms (cf. czso.cz). Two districts of the Central Bohemia region, Prague-West and Prague-East, surround the capital. The other districts of Central Bohemia, Benešov, Beroun, Kladno, Kolín, Kutná Hora, Mělník, Mladá Boleslav, Nymburk, Příbram, and Rakovník, largely comprise the growing suburban area around the capital. In total, Central Bohemia has now more inhabitants than Prague, at over 1,330,000, with Kladno being the most populous district at about 160,000 (ČSÚ 2011). Central Bohemia could be described as a periphery vis-à-vis Prague: people commute to Prague for work, and conversely, Prague's inhabitants seek recreation in Central Bohemia. The interconnection with Prague is fundamental to Central Bohemia and is not limited to economic matters.

To clarify the situation, we once again present the values of the coefficient of variation, which are relatively high for all cases. Thus, it cannot be stated that electoral support for the Green Party is spread uniformly across the municipalities of Central Bohemia. In fact, the opposite holds true: municipalities can be located with very low and very high support. The value of the coefficient was highest in 2010, indicating a presence in Central Bohemia of municipalities, where the Green Party commanded important support, as well as in others where it commanded hardly any. Therefore, it can be stated that the support for the Green Party in Central Bohemia has not been territorially homogeneous.

Table 8: Variability in electoral support for the Green Party in Central Bohemia $(\mathrm{N}=1,144)$

\begin{tabular}{|l|c|c|c|}
\hline & $\mathbf{2 0 0 6}$ & $\mathbf{2 0 1 0}$ & $\mathbf{2 0 1 3}$ \\
\hline Coefficient of variation & 0.47 & 0.75 & 0.63 \\
\hline
\end{tabular}

Source: www.volby.cz, authors' calculation.

Table 9 shows the values for the coefficient of correlation. A positive relationship exists between all the election results in Central Bohemia, and the value of the coefficient is substantial in every case. Graphical representations of electoral support for the Green Party in all three elections would be expected to overlap, creating a fairly homogeneous map of territorial support, which contrasts with results obtained at the national level. We can examine individual tendencies in greater detail, using a regression model focused on the influence of selected indicators. 
Table 9: Stability of the Green Party's electoral base in Central Bohemia $(\mathbf{N}=$ $1,144)$

\begin{tabular}{|c|c|c|c|}
\hline & $\mathbf{2 0 0 6}$ & $\mathbf{2 0 1 0}$ & $\mathbf{2 0 1 3}$ \\
\hline $\mathbf{2 0 0 6}$ & 1 & 0.466 & 0.456 \\
\hline $\mathbf{2 0 1 0}$ & 0.466 & 1 & 0.595 \\
\hline $\mathbf{2 0 1 3}$ & 0.456 & 0.595 & 1 \\
\hline
\end{tabular}

Note: weighted by the population living in municipalities in 2010.

Source: www.volby.cz, authors' calculation.

A regression analysis of the causal relationship between the Green Party's electoral gains and the indicators of post-materialism for Central Bohemia produced results fairly similar to those obtained at the national level (see Table 10). The values of the beta coefficient, determining the significance of the causal relationship, were also relatively low for the variables 'city', 'unemployment rate', and 'lower age'. Nevertheless, the influence of these variables on the Green Party's election results is rather marginal. A more important influence can be observed when applying the variables 'university education'. The value of the coefficient is highest in the last-mentioned case, which indicated that if the proportion of people with a university education in the municipalities of Central Bohemia were to increase by 1 percentage point, the election results of the Green Party would improve by 0.188 percentage points.

Table 10: Influence of indicators on the Green Party's electoral gains in Central Bohemia $(\mathbf{N}=1,144)$

\begin{tabular}{|l|c|c|c|c|c|c|}
\hline \multirow{2}{*}{} & \multicolumn{2}{|c|}{2006} & \multicolumn{2}{c|}{2010} & \multicolumn{2}{c|}{2013} \\
\cline { 2 - 7 } & Beta & St. Beta & Beta & St. Beta & Beta & St. Beta \\
\hline Constant & 1.552 & & -0.045 & & 1.452 & \\
\hline Lower age & 0.111 & 0.120 & 0.020 & 0.033 & -0.009 & -0.010 \\
\hline $\begin{array}{l}\text { Middle and upper class } \\
\text { /income }\end{array}$ & 0.012 & 0.077 & 0.008 & 0.087 & 0.003 & 0.026 \\
\hline University education & 0.152 & 0.389 & 0.119 & 0.499 & 0.188 & 0.591 \\
\hline City & 0.654 & 0.121 & -0.253 & -0.071 & 0.317 & 0.064 \\
\hline Unemployment rate & 0.003 & 0.005 & 0.013 & 0.045 & 0.001 & 0.002 \\
\hline Index of determination & \multicolumn{2}{|c|}{0.214} & \multicolumn{2}{|c|}{0.290} & \multicolumn{2}{c|}{0.377} \\
\hline
\end{tabular}

Note: weighted by the population living in municipalities in 2006, 2010 and 2013.

Data source: www.volby.cz, www.czso.cz, www.mpsv.cz, authors' calculation. 
The somewhat different interpretation of the outputs of the statistical analysis for the Central Bohemia region presented above can be explained by reference to the ring of electoral support for the Green Party around the capital (see Table 11). The districts Prague-East and Prague-West are considered as suburbs of Prague. In terms of societal characteristics, they are more similar to Prague than to the remaining districts of Central Bohemia. This is particularly so with respect to their lower unemployment rate, which is as typical of these districts as of the capital (ČSÚ 2014; MPSV 2014). This explains the differing values in the coefficients produced by the correlation and regression analysis. Thus, the regression analysis for the two districts Prague-East and Prague-West showed lower level of index of determination. Again, university education at the level of each municipality is the best indication for better results of Green Party. Very low or unstable is lower age, income and unemployment rate. The similarity between the municipalities in the two districts around Prague with Prague allowed us to infer that a detailed analysis of the territory of the latter would produce similar results.

Table 11: Influence of indicators on the Green Party's electoral gains around Prague $(\mathbf{N}=189)$

\begin{tabular}{|l|c|c|c|c|c|c|}
\hline \multirow{2}{*}{} & \multicolumn{2}{|c|}{2006} & \multicolumn{2}{c|}{2010} & \multicolumn{2}{c|}{2013} \\
\cline { 2 - 7 } & Beta & St. Beta & Beta & St. Beta & Beta & St. Beta \\
\hline Constant & 0.480 & & 1.376 & & 0.751 & \\
\hline Lower age & 0.214 & 0.228 & 0.039 & 0.058 & -0.024 & -0.025 \\
\hline $\begin{array}{l}\text { Middle and upper class } \\
\text { /income }\end{array}$ & 0.016 & 0.064 & 0.000 & 0.000 & 0.010 & 0.054 \\
\hline University education & 0.119 & 0.317 & 0.126 & 0.487 & 0.139 & 0.470 \\
\hline Unemployment rate & -0.164 & -0.117 & -0.106 & -0.240 & 0.244 & 0.196 \\
\hline Index of determination & \multicolumn{2}{|c|}{0.197} & \multicolumn{3}{|c|}{0.244} & \multicolumn{2}{c|}{0.286} \\
\hline
\end{tabular}

Note: weighted by the population living in municipalities in 2006, 2010 and 2013.

Source: www.volby.cz, www.czso.cz, www.mpsv.cz, authors' calculation.

\section{LIBEREC REGION}

The position of the Liberec region is apparently less economically advantageous than that of Central Bohemia, and the commuting distance to the capital is much greater. Located at the very north of the Czech Republic, Liberec is one of the country's smaller regions in terms of area and population, that is, less than $450,000^{5}$. It consists of the districts Česká Lípa, Jablonec nad Nisou, Liberec and Semily. Formerly, the region was characterised by widespread industry and mining in Stráž pod Ralskem.

${ }^{5}$ Czech Statistical Office in annual report 31. 12. 2013 (https://www.czso.cz/csu/xl). 
Table 12 summarizes the values of the coefficient, indicating variability in electoral support for the Green Party in the municipalities of the Liberec region. It shows that in the 2010 election, when the Green Party fared the worst out of the three elections analysed, its results where highly heterogeneous across the region. In the other two elections, the variability of its electoral support in the Liberec region was less pronounced.

Table 12: Variability in electoral support for the Green Party in the Liberec region $(\mathrm{N}=215)$

\begin{tabular}{|c|c|c|c|}
\hline & 2006 & 2010 & 2013 \\
\hline $\begin{array}{c}\text { Coefficient of } \\
\text { variation }\end{array}$ & 0.45 & 1.00 & 0.57 \\
\hline
\end{tabular}

Source: www.volby.cz, authors' calculation.

The values of Pearson's correlation coefficient provided in Table 13 reveal that the stability of the Green Party's electoral base in the municipalities of the Liberec region is not low. In all cases, the values of the coefficient testify to intermediate relationship. A regression analysis of the causal relationship between the Green Party's electoral gains and the indicators of post-materialism produced different results for the municipalities of the Liberec region from those obtained at previous levels.

Table 13: Stability of the Green Party's electoral base in the Liberec region $(\mathbf{N}=215)$

\begin{tabular}{|c|c|c|c|}
\hline & 2006 & 2010 & 2013 \\
\hline 2006 & 1 & 0.455 & 0.358 \\
\hline 2010 & 0.455 & 1 & 0.542 \\
\hline 2013 & 0.358 & 0.542 & 1 \\
\hline
\end{tabular}

Note: weighted by the population living in municipalities in 2010 .

Source: www.volby.cz, authors' calculation.

Similar to the previous case, Table 14 shows the significance of the causal relationship. The best position belongs to university education, others are not so important or unstable. A more substantial influence can only be observed for the variable 'university education', where an increase by one unit would improve the gains of the Green Party by about 0,6 a percentage point in 2006, in other elections is it less. And also in this year the share of explain variability is highest. 
Table 14: Influence of indicators on the Green Party's electoral gains in Liberec region $(\mathrm{N}=215)$

\begin{tabular}{|l|c|c|c|c|c|c|}
\hline \multirow{2}{*}{} & \multicolumn{2}{|c|}{2006} & \multicolumn{2}{c|}{2010} & \multicolumn{2}{c|}{2013} \\
\cline { 2 - 7 } & Beta & St. Beta & Beta & St. Beta & Beta & St. Beta \\
\hline Constant & 3.776 & & 1.551 & & 1.160 & \\
\hline Lower age & 0.199 & 0.095 & -0.020 & -0.023 & 0.128 & 0.193 \\
\hline $\begin{array}{l}\text { Middle and upper class } \\
\text { /income }\end{array}$ & -0.055 & -0.096 & -0.003 & -0.013 & -0.019 & -0.119 \\
\hline University education & 0.615 & 0.760 & 0.261 & 0.763 & 0.180 & 0.777 \\
\hline City & 0.232 & 0.041 & -0.928 & -0.388 & -0.597 & -0.368 \\
\hline Unemployment rate & 0.388 & 0.385 & -0.018 & -0.049 & 0.024 & 0.054 \\
\hline Index of determination & \multicolumn{2}{|c|}{0.462} & \multicolumn{3}{|c|}{0.291} & \multicolumn{2}{c|}{0.265} \\
\hline
\end{tabular}

Note: weighted by the population living in municipalities in 2006, 2010 and 2013.

Source: www.volby.cz, www.czso.cz, www.mpsv.cz, authors' calculation.

\section{Conclusion}

In this paper, we have sought to answer the following question: Has there been in Czech society - described in a number of studies as a post-materially oriented one - a positive response to a classic representative of post-materialist politics, the Green Party? In 2006, the party crossed the election threshold and won seats in the lower chamber of the Czech parliament. Our main focus has been on the territorial distribution of the Green Party's electoral support and its correlation with post-materialism, understood here via the influence of selected variables that should indicate a post-materially oriented society, which is thought to constitute a prerequisite for the success of a 'green' party.

In the introduction, we established the basic objectives of this study and the research questions it sought to answer; here we evaluate the results. We defined five indicators of post-materialism: lower age, university education, middle and upper class/income, as well as indicators on municipal level such as lower unemployment rate, and larger municipality size. First, we have observed the relationships and influences between electoral support for the Green Party and indicators at the national level. Having compared the electoral results from 2006 to 2013, the regions showing higher electoral support for the Green Party were established as Central Bohemia and Liberec. For the former, we also analysed the districts immediately adjacent to the capital in greater detail. We found relationships between electoral support for the Green Party and municipalities with a higher proportion of post-materialistically oriented voters, but not in every case and not to the same level. At the national level in the three elections studied, a positive correlation was established for two of the five indicators: the proportion 
of the population for members of, respectively, the middle and the upper classes, and those with university education. By contrast, for the variables 'city' and 'unemployment rate', no correlation was established. A regression analysis produced similar outcomes: greatest influence was repeatedly recorded for the variables 'university education'. The findings were particularized further at lower levels in two regions, Central Bohemia and Liberec, and in two districts, PragueWest and Prague-East. In the two regions, besides the importance of the variable 'university education', a small but positive influence from the variables 'lower age' in 2006.

For the two districts around Prague, it is possible to state that a lower unemployment rate; a higher proportion of the university educated; and, to a smaller degree, a higher proportion of younger voters in 2006, have all positively influenced electoral support for the Green Party. Thus, we can state in conclusion that there is a relationship between votes for the Green Party and municipalities with more post-materialistic voters, but that this relationship varies in intensity depending on the region, and on whether the analysis is undertaken at the national, regional, or district level.

The findings cited indicate that there are connections and influences between post-materially oriented regions and support for the Green Party, but the relationship is not particularly strong. Future research might want to focus on qualitative surveys of the perception of post-material values in society and their connection with politics. Given the recent developments in Czech politics, it is possible that the Green Party does not provide the ideal choice for a post-material voter, as there might be other, and perhaps more suitable, representatives of postmaterialism. This might be due in part to a looser conception of post-materialism as it tends to be understood in the country. Plainly said, it seems that the Czech Green Party got the priorities of Czech post-materialist voters wrong, or, expressed differently, Czech post-materialist voters are interested in issues other than those highlighted by the Green Party in 2006-2013. Future research would do well to concentrate on comparing the priorities of Czech post-materialist voters with those of the electorates in other countries and observe the similarities and differences in the positions of 'green' parties in the Czech Republic, Germany, Austria and other countries. The findings of this study indicate that Czech society is post-materialist, but that the Czech Green Party is not the best advocate of such values.

\section{References}

Balík, Stanislav and Jan Holzer and Lubomír Kopeček (2008): "Czechoslovakia in 1989 a case of successful transition." Totalitarismus und Demokratie 5(1), 19-42.

Berger, Peter L. (1986): The Capitalist Revolution. Fiffy Propositions about Prosperity, Equality and Liberty. New York: Basic Books. 
Burchell, Jon (2002): The Evolution of Green Politics: Development and Change within European Green Parties. London: Sterling.

Czech Statistical Office (Český statistický úřad) 2017. SLDB [online]. Available from http://sldb.cz [Accessed 5 December 2017].

Chytilek, Roman (2000): Dva pohledy na politickou dimenzi postmaterialismu. Brno: Masarykova univerzita.

ČSÚ (2012): Czech Statistical Office: Summary data on the Czech Republic [online]. Available at https://www.czso.cz/csu/czso/summary_data_on_the_czech_republic [Accessed December 16, 2014].

De Vaus, David (2002): Surveys in Social Research. St. Leonards: Allen\&Unwin.

Duch, Raymond M. and Michaell A. Taylor (1993): "Postmaterialism and Economic Condition." American Journal of Political Science 37(3), 747-779.

Easterly, William (2001): "The Middle Class Consensus and Economic Development." Journal of Economic Growth 6(4), 317-335. DOI: 10.1023/A:1012786330095

European V alues Study (EVS) [online]. Available from http://www.europeanvaluesstudy.eu/ [Accessed 22 October 2014].

Grofman, Bernard and Samuel Merill III (1999): A Unified Theory of Voting. Directional and Proximity Spatial Models. Cambridge University Press.

Hendl, Jan (2006): Prebled statistických metod zpracováni dat: analýza a metaanalýza dat. Praha: Portál. Heywood, Andrew (2012): Political Ideologies. Basingstoke: Palgrave Macmillan.

Ignazi, Pietro (1992): “The Silent Counter Revolution: Hypotheses on the Emergence of the Extreme Right - Wing Parties in Europe." European Journal of Political Research 22(1), 3-34. DOI: 10.1111/j.1475-6765.1992.tb00303.x

Ignazi, Pietro (1996): “The Crisis of Parties and the Rise of New Political Parties." Party Politics 2(4), 549-566. DOI: 10.1177/1354068896002004007

Inglehart, Ronald (1971): "The Silent Revolution in Europe: Intergenerational Change in Post - Industrial Societies." American Political Science Review 65(4), 991-1017. DOI: $10.2307 / 1953494$

Inglehart, Ronald (1977): The Silent Revolution: Changing Values and Political Systems among Western Publics. Princeton University Press.

Inglehart, Ronald and Miguel Besanez and Alejandro Moreno (1998): Human Values and Beliefs. Ann Arbor: The University of Michigan Press.

Jehlička, Petr and Tomáš Kostelecký and Daniel Kunštát (2011): “Czech Green politics after two decades: the May 2010 general election.” Environmental Politics, 20 (3), 418-425. DOI: $10.1080 / 09644016.2011 .573365$

Kostelecký, Tomáš (2009): "Regionální rozdíly ve volebních výsledcích v České republice parlamentní volby 1996-2006." Evropská volebni studia/European Electoral Studies 4(2), 124-134. Kostelecký, Tomáš and Daniel Čermák (2003): "Výběrová šetření a analýza agregátních dat - diskuze na téma použitelnosti různých př́stupů v komparativních analýzách politického chování." Sociologický časopis 39(4), 529-550.

Kramer, Gerald H. (1983): "The ecological fallacy revisited: Aggregate-versus individuallevel findings on economics and elections, and sociotropic voting." American Political Science Review 77(1): 92-111. DOI: 10.2307/1956013

Lipset, Seymour M. 1981. Political Man. The Social Basis of Politics. Baltimore: The John Hopkins University Press. 
Lipsitz, Lewis (1965): “Working-class authoritarianism: A re-evaluation." American Sociological Review 30(1), 103-109. DOI: 10.2307/2091777

Møller, Jorgen (2009): Post-communist Regime Change: A Comparative Study. New York: Routledge.

OECD (2010): Latin American Economic Outlook 2011: How Middle-Class is Latin America, Paris: OECD Publishing [online]. Available fromhttp://www.latameconomy.org/ fileadmin/uploads/laeo/Documents/E-book_LEo2011-EN_entier.pdf [Accessed 26 October 2014].

Pečínka, Pavel (2002): Zelená ₹leva? Historie ekologickéch stran Evropě. Praha: G plus G.

Rabušic, Ladislav (2000): "Je česká společnost postmaterialistická?" Sociologickéy časopis 36(1), 3-22.

Robinson W. S. (1950): "Ecological correlations and the behavior of individuals." American Sociological Review 15(3), 351-357. DOI: 10.2307/2087176

The Ministry of Labour and Social Affairs (2013): Mèsični statistika nezaměstnanosti[online]. Available from http://portal.mpsv.cz/sz/stat/nz/mes L [Accessed 18 December 2014].

Tingsten, Herbert (1937): "Political Behaviour; Studies in Election Statistics." Stockholm Economic Studies 7, London: PS King.

Tranter, Bruce and Mark Western (2009): "The Influence of Green Parties on Postmaterial Values." The British Journal of Sociology 60(1), 145-167. DOI: 10.1111/j.14684446.2008.01222.x

Večerník, Jiří and Petr Matějů (1998): Zpráva o vývoji české společnosti 1989-1998. Praha: Academia.

Volby.cz (2014): [online]. Available from http://volby.cz/ [Accessed 15 November 2014].

Weakliem, David L. (1991): "The Two Lefts? Occupation and Party Choice in France, Italy and the Netherlands." American Journal of Sociology 96 (6), 1327-1361. DOI: $10.1086 / 229689$

White Riley, M. 1972. Aging and Society. New York: Russel Sage Fundation.

World Values Survey (2014). World Values Survey [online]. Available at http://www.worldvaluessurvey.org/ wvs.jsp [Accessed 5 November 2014] 